\title{
SIMULASI PREDIKSI JUMLAH MAHASISWA BARU UNIVERSITAS DEHASEN BENGKULU MENGGUNAKAN METODE MONTE CARLO
}

\author{
Abdussalam Al Akbar ${ }^{1}$, Hendri Alamsyah ${ }^{2}$, Riska $^{3}$ \\ ${ }^{1}$ Informatika, Ilmu Komputer, Universitas Dehasen, Jl. Meranti raya No.23 Bengkulu, 38228 \\ ${ }^{2,3}$ Rekayasa Sistem Komputer, Ilmu Komputer, Universitas Dehasen, Jl. Meranti raya No.23 Bengkulu, 38228
}

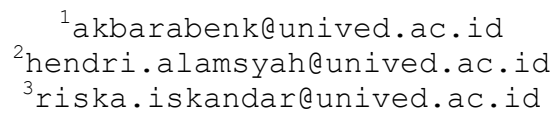

Abstract: Dengan adanya sistem simulasi prediksi jumlah mahasiswa baru ini, diharapkan dapat memprediksi jumlah mahasiswa baru yang masuk pada setiap tahun kedepan nya. Menerapkan metode Monte Carlo dan juga menerapkan aplikasi simulasi prediksi ini sekaligus menguji tingkat akurasi dan efisiensi data yang dihasilkan menggunakan metode ini. Pengumpulan data yang dilakukan dengan cara obeservasi secara langsung ke objek dengan mengambil sampel data yang sudah ada di tahun 2013 2017 untuk dapat memprediksi ditahun berikutnya. Melakukan analisis terhadap sistem yang berjalan untuk kemudian dijadikan bahan untuk merancang dan membangun aplikasi dengan menggunakan bahasa pemrograman yaitu Visual Basic. Hasil dari pengujian terhadap metode ini adalah dari berapa banyak jumlah mahasiswa baru setiap tahunnya dan akan dilihat tingkat keakuratannya. Maka dapat disimpulkan bahwa penggunaan Metode Monte Carlo dalam penelitian ini adalah sebagai metode yang dapat memberikan informasi mengenai keuntungan maksimum yang dihasilkan melalui percobaan bilangan acak. Semakin banyak percobaan dilakukan, maka akan semakin baik hasilnya..

Kata Kunci: Simulasi, Prediksi, Monte Carlo.

\begin{abstract}
With the prediction simulation system, the number of new college students is expected to predict the number of new college students coming in every year in the future. Applying the Monte Carlo method and also implementing this predictive simulation application simultaneously test the accuracy and efficiency of the data generated using this method. Data collection is done by obeservasi directly to the object by taking samples of existing data in the year 2013 - 2017 to be able to predict the next year. Perform analysis of the system that runs for later used as materials to design and build applications using programming language that is Visual Basic. The result of testing on this method is from how many new college students each year and will see the level of accuracy. So it can be concluded that the use of Monte Carlo Method in this study is as a method that can provide information about the maximum benefit generated through random number experiments. The more experiments done, the better the results.
\end{abstract}

Keywords: Simulation, Prediction, Monte Carlo.

\section{PENDAHULUAN}

Penerimaan mahasiswa baru (PMB) merupakan aktivitas rutin tahunan yang dilakukan di sekolah maupun universitas. Universitas dehasen sebagai salah satu perguruan tinggi swasta favorit dibengkulu yang akan melaksanakan penerimaan calon mahasiswa baru. Sistem penerimaan mahasiswa baru ini masih sangat manual dalam hal memperkirakan atau memprediksi berapa jumlah mahasiswa yang akan di terima juga masih belum bisa di pastikan berapa hasilnya. Untuk memenuhi kebutuhan diatas dapat dilakukan dengan pemodelan dan simulasi, dengan cara mengambil sampel data penerimaan mahasiswa baru di tahun sebelumnya sehingga dapat di prediksi untuk tahun kedepannya. Salah satunya dengan menggunakan 
Jurnal Pseudocode, Volume VII Nomor 1, Februari 2020, ISSN 2355-5920, e-ISSN 2655-1845 www.ejournal.unib.ac.id/index.php/pseudocode

metode Monte Carlo. Dasar dari Simulasi Monte Carlo adalah percobaan elemen kemungkinan dengan menggunakan sampel random. Simulasi Monte Carlo dalam penentuan nilai opsi dapat dihitung dengan menggunakan software matlab, visual basic dan PHP. [1]

Dalam hal ini metode Monte Carlo juga dijuluki self-learning monte carlo (SLMC) dimana sebuah algoritma efisien pertama kali belajar dari data pelatihan yang dihasilkan dalam simulasi dan kemudian digunakan untuk mempercepat simulasi sebenarnya. [2]

Metode Monte Carlo adalah pendekatan yang sangat umum dan berguna untuk memperkirakan ekspektasi yang timbul dari simulasi stokastik. Namun, harganya bisa mahal secara komputasi, terutama bila biaya menghasilkan sampel stokastik individual sangat tinggi, seperti pada kasus PDE stokastik. Multilevel Monte Carlo adalah pendekatan yang baru dikembangkan yang sangat mengurangi biaya komputasi dengan melakukan sebagian besar simulasi dengan akurasi rendah dengan biaya rendah, dengan sedikit simulasi yang dilakukan dengan akurasi tinggi dan biaya tinggi. [3]

Pada metode Monte Carlo dengan algoritma Metropolis proses pemodelan dimulai dengan mensubsititusikan parameter model awal.Dari hasil simulasi diperoleh bahwa kemiripan pola terhadap deret waktu tersebut dimiliki oleh deret Fourier yang berorde besar, yaitu pada orde 17. Hasil estimasi tersebut kemudian divalidasi dengan data tahun 2011 hingga 2012 menghasilkan koefisien korelasi sebesar 0,68. [4]

Analisa yang dalam keseluruhan prosesnya membutuhkan pengukuran terhadap ketidakpastian dan kombinasi probabilitas dari ketidakpastian individu. Analisa kuantitatif ini kadangkala membutuhkan program komputer. Salah satu teknik yang dipakai untuk analisa risiko secara kuantitatif dan teknik pemodelan adalah Monte Carlo Modeling and Simulation. [5].

\section{LANDASAN TEORI}

\section{A. Simulasi}

suatu proses peniruan dari sesuatu kata yang nyata beserta keadaan sekelilingnya. Simulasi ini secara umum menggambarkan karakteristik kunci dari kelakuan sistem fisik atau sistem yang abstrak tertentu. Simulasi ialah suatu metodologi untuk melaksanakan percobaan dengan menggunakan model dari satu sistem nyata. Simulasi juga dapat memberikan penyelidikan yang langsung dan terperinci dalam periode waktu khusus. Simulasi tidak menghasilkan jawaban, tetapi ia menghasilkan cara untuk menilai jawaban termasuk jawaban optimal. [6]

Langkah-langkah dalam simulasi dapat dituliskan sebagai berikut:

1. Formulasi Masalah dan Tujuan Studi Formulasi masalah melibatkan spesifikasi yaitu kriteria kinerja di mana aturan-aturan keputusan alternatif akan dievaluasi, variabel keadaan, dan parameter sistem.

2. Membangun Model Simulasi Langkah penting dalam simulasi adalah membangun model yang menggambarkan kondisi riil masalah yang akan disimulasikan.

3. Validasi Model Simulasi Di dalam validasi model simulasi digunakan uji kesamaan dua varians (homogenitas) dan uji kesamaan dua rata-rata.

a. Uji kesamaan Dua Varians (Homogenitas)

$$
F_{\text {hitung }}=\frac{\text { varians } 1}{\text { varians } 2}
$$

dengan wilayah kritis yaitu Fhitung > 
Jurnal Pseudocode, Volume VII Nomor 1, Februari 2020, ISSN 2355-5920, e-ISSN 2655-1845 www.ejournal.unib.ac.id/index.php/pseudocode

Ftabel di mana Ftabel di mana Ftabel diperoleh dari tabel distribusi F dengan nilai $\alpha=5 \%$ dan $\mathrm{dk}=\mathrm{n}-1$

b. Uji kesamaan Dua Rata - Rata

$$
t_{\text {hitung }}=\frac{X_{1}-X_{2}}{s^{2} g a b \sqrt{\frac{1}{n 1}+\frac{1}{n a}}}
$$

dengan kriteria pengujian yaitu $H_{0}$ dapat diterima jika $-t_{\text {tabel }} \leq t_{\text {hitung }} \leq_{+} t_{\text {tabel }}$ di mana $t_{\text {tabel }}$ diperoleh dari tabel distribusi $t$ dengan nilai $\alpha=5 \%$ dan $d k=n_{1}+n_{2}$ $-2$

Keterangan:

a : distribusi kedatangan

b : distribusi keberangkatan atau waktu pelayanan

c : banyaknya pelayanan parallel

$\mathrm{d}:$ disiplin pelayanan

e : jumlah maksimal pengantri dalam sistem (antri dan dilayani)

f : jumlah sumber kedatangan.

c. Analisis hasil Simulasi

Analisis hasil simulasi dilakukan dengan mencoba berbagai bentuk variabel jawab untuk menemukan solusi dari persoalan.

\section{B. Prediksi}

Prediksi atau peramalan merupakan aktivitas fungsi bisnis yang memperkirakan penjualan dan penggunaan produk sehingga produk-produk itu dapat dibuat dalam kuantitas yang tepat. Peramalan merupakan dugaan terhadap permintaan yang akan datang berdasarkan pada beberapa variabel peramal, sering berdasarkan data deret waktu historis. Hal ini dapat dilakukan dengan melibatkan pengambilan data masa lalu dan menempatkannya ke masa yang akan datang dengan suatu bentuk model matematis. [7] Berdasarkan horison waktu, peramalan dapat dikelompokkan dalam tiga bagian yaitu :
1. Peramalan jangka pendek, Peramalan ini mencakup jangka waktu hingga satu tahun tetapi umumnya kurang dari 3 bulan.

2. Peramalan jangka menengah atau intermediate, umumnya mencakup hitungan bulanan hingga 3 tahun.

3. Peramalan jangka panjang, Umumnya untuk perencanaan 3 tahun atau lebih.

Efektivitas sistem peramalan dalam membantu organisasi dapat dievaluasi berdasarkan empat kriteria berikut:

a. Accuracy ini merupakan aspek terpenting dari forecast, karena perbedaan antara aktual dan forecast berarti biaya.

b. Stability vs Responsiveness. Artinya forecast harus mampu mengkover kompleksitas dan ketidakpastian lingkungan baik yang disebabkan oleh long term growth trend maupun seasonal influences.

c. Objectivity. Kadang-kadang kondisi yang diramalkan tidak dapat atau tidak ada kaitannya dengan data historis yang digunakan dalam forecasting.

d. Timing. Agar sistem forecasting dapat efektif, maka forecast harus tersedia tepat waktu.

e. Benefit to Cost Ratio. Merupakan perbandingan antara manfaat yang berupa perbaikan kualitas keputusan sehubungan dengan adanya sistem peramalan yang diukur dengan cost saving dan biaya untuk membangun dan memelihara sistem peramalan.

Monte Carlo salah satu teknik yang dapat digunakan untuk menganalisis resiko adalah dengan melakukan simulasi Monte Carlo. Simulasi Monte Carlo secara random menghitung nilai dari 
Jurnal Pseudocode, Volume VII Nomor 1, Februari 2020, ISSN 2355-5920, e-ISSN 2655-1845 www.ejournal.unib.ac.id/index.php/pseudocode

variabel - variabel yang tidak pasti secara berulang-ulang untuk mensimulasi sebuah model. Perhitungan yang berulang bertujuan untuk mendapatkan distribusi probabilitas dari model yang disimulasikan. Hal yang diharapkan dengan dengan dilakukan simulasi ini adalah dapat mengambil keputusan yang sesuai dan tepat. Sebuah model optimasi dapat menganalisis keputusan yang akan di ambil dan memberikan solusi yang terbaik. [8]

Simulasi Monte Carlo adalah Salah satu metode sederhana yang dapat dibangun secara cepat dengan hanya menggunakan spreadsheet misalnya Microsoft Excell. [9] model simulasi Monte Carlo di dasarkan pada probabilitas yang diperoleh data historis sebuah kejadian dan frekuensinya, dimana:

$$
\mathrm{Pi}=\mathrm{fi} / \mathrm{n}
$$

Pi : $\quad$ Probabilitas kejadian i

fi : $\quad$ frekuensi kejadian i

n : jumlah frekuensi semua kejadian.

Tetapi dalam simulasi Monte Carlo probabilitas juga dapat ditentukan dengan mengukur probabilitas sebuah kejadian terhadap suatu distribusi tertentu.

Pengambilan keputusan dapat mengestimasi nilai prosentase minimum, paling mungkin, dan maksimum untuk calon mahasiswa yang mendaftar ulang berdasarkan tiap faktor. Distribusi segitiga dapat digunakan untuk distribusi yang berdasarkan opini ahli. [10] Ada beberapa contoh perhitungan yang menggunakan metode Monte Carlo yang akan digunakan untuk membangkitkan bilangan acak dengan distribusi uniform dan Pseudo RNG, berbentuk:

$$
\mathrm{Zi}=(\mathrm{aZi}-1+c) \bmod m
$$

Dimana :

$\mathrm{Zi}=$ bilangan acak ke-i dari deretnya
Zi-1 = bilangan acak sebelumnya

$$
\begin{aligned}
& \mathrm{a}=\text { faktor pengali } \\
& \mathrm{c}=\text { increment } \\
& \mathrm{m}=\text { modulus }
\end{aligned}
$$

kunci pembangkit adalah Z0 yang disebut umpan (seed)

a. Contoh Linear Congruential Generator (LCG) 1 :

Membangkitkan bilangan acak sebanyak 8 kali dengan $\mathrm{a}=2, \mathrm{c}=7, \mathrm{~m}=10$, dan $\mathrm{Z} 0=2$

$\mathrm{Z} 1=(2.2+7) \bmod 10=1$

$\mathrm{Z} 2=(2.1+7) \bmod 10=9$

$\mathrm{Z} 3=(2.9+7) \bmod 10=5$

$\mathrm{Z} 4=(2.5+7) \bmod 10=7$

$\mathrm{Z} 5=(2.7+7) \bmod 10=1$

$\mathrm{Z} 6=(2.1+7) \bmod 10=9$

$\mathrm{Z7}=(2.9+7) \bmod 10=5$

$\mathrm{Z} 8=(2.5+7) \bmod 10=7$

Bilangan acak yang dibangkitkan adalah :

$\begin{array}{lllllllll}1 & 9 & 5 & 7 & 1 & 9 & 5 & 7 & \text { jadi }\end{array}$

terjadi pengulangan bilangan secara periodik.

b. Contoh Linear Congruential Generator (LCG) 2:

Membangkitkan bilangan acak sebanyak 8 kali dengan $\mathrm{a}=4, \mathrm{c}=7, \mathrm{~m}=15$, dan $\mathrm{Z} 0=3$

$\mathrm{Z} 1=(4.2+7) \bmod 15=4$

$\mathrm{Z} 2=(4.4+7) \bmod 15=8$

$\mathrm{Z3}=(4.8+7) \bmod 15=9$

$\mathrm{Z} 4=(4.9+7) \bmod 15=13$

$\mathrm{Z} 5=(4.13+7) \bmod 15=14$

$\mathrm{Z6}=(4.14+7) \bmod 15=3$

$\mathrm{Z7}=(4.3+7) \bmod 15=4$

$\mathrm{Z} 8=(4.4+7) \bmod 15=8$

Bilangan acak yang dibangkitkan adalah : $\begin{array}{llllllll}4 & 8 & 9 & 13 & 14 & 4 & 8 & \text { jadi }\end{array}$ tidak terjadi pengulangan secara periodik. 
Jurnal Pseudocode, Volume VII Nomor 1, Februari 2020, ISSN 2355-5920, e-ISSN 2655-1845 www.ejournal.unib.ac.id/index.php/pseudocode

\section{METODE PENELITIAN}

Metodologi penelitian ini memuat gambaran atau langkah - langkah yang akan dilaksanakan dalam melakukan penelitian. Ini perlu ditetapkan supaya penelitian dapat dilakukan dengan terstruktur. Langkah yang akan dilakukan harus mencakup mulai dari mempelajari masalah sampai dengan adanya suatu sistem yang dapat dihasilkan sehingga masalah dapat teratasi.

\section{A. Planning}

Dalam pengembangan yang digunakan dalam penelitian ini yaitu model Alessi dan Trollip kemudian digunakan dengan tujuan dan kondisi penelitian yang sebenarnya. Tahap penelitian terbagi menjadi dua tahapan yaitu 1) Tahap Planning dan 2) Tahap Procces. Selanjutnya penerapan penelitian dan pengembangan yang dilakukan terdiri atas 5 langkah serta satu proses hasil simulasi, seperti terlihar pada gambar 1 .

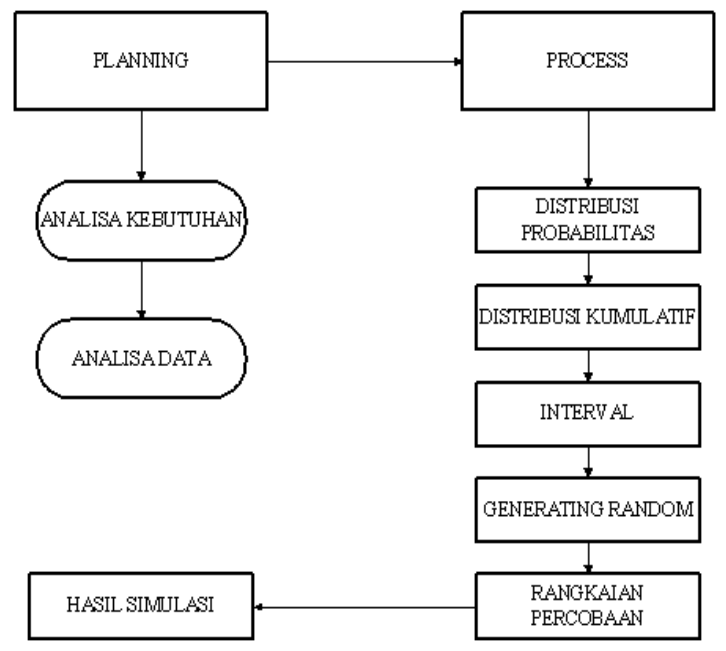

Gambar 1. Pengembangan Proses Alessi dan Trollip

B. Proses

Setelah proses menggunakan metode dilakukan, maka langkah selanjutnya menentukan Simulasi Monte Carlo dengan 5 Langkah yang ada.
1. Menetapkan atau menentukan distribusi probabilitas untuk variable-variabel penting.

2. Menghitung distribusi kumulatif untuk setiap variable pada langkah 1 .

3. Menetapkan Suatu Interval dari angka acak (random numbers) untuk masing-masing interval.

4. Bentuk bilangan acak (Generating Random Numbers) Dengan menggunakan metode kongruen campuran (mixed congruent method)

Rumus untuk Generate Random Number :

\section{a. Mixed Congruent Method \\ b. Multiplicative Method}

5. Simulasikan dari Rangkaian Percobaan dengan menghubungkan angka acak dengan interval angka acak.

C. Pengolahan Data dengan Algoritma Rancangan Pada penelitian ini penulis mengimplementasikan pengujian model dari hasil perancangan sistem dengan menggunakan alat bantu komputer dengan operating system windows 10 dan aplikasi menggunakan bahasa Visual Basic.

\section{ANALISA DAN PEMBAHASAN}

A. Analisa Perancangan Sistem

Untuk melakukan penganalisaan sebuah sistem yang tepat dalam simulasi memprediksi jumlah mahasiswa baru dengan menggunakan metode monte carlo diperlukan suatu analisa kebutuhan sistem yang akan dibangun, dimana dalam sebuah pembangunan sistem ini diperlukan suatu pemahaman yang akan penulis ketahui dan akan temukan.

B. Arsitektur Sistem Pengolahan Data

Berikut ini akan digambarkan dan dijelaskan alur proses arsitektur pengolahan data simulasi 
Jurnal Pseudocode, Volume VII Nomor 1, Februari 2020, ISSN 2355-5920, e-ISSN 2655-1845 www.ejournal.unib.ac.id/index.php/pseudocode

dalam memprediksi jumlah mahamahasiswa baru di Universitas Dehasen Bengkulu dengan menggunakan metode Monte Carlo.

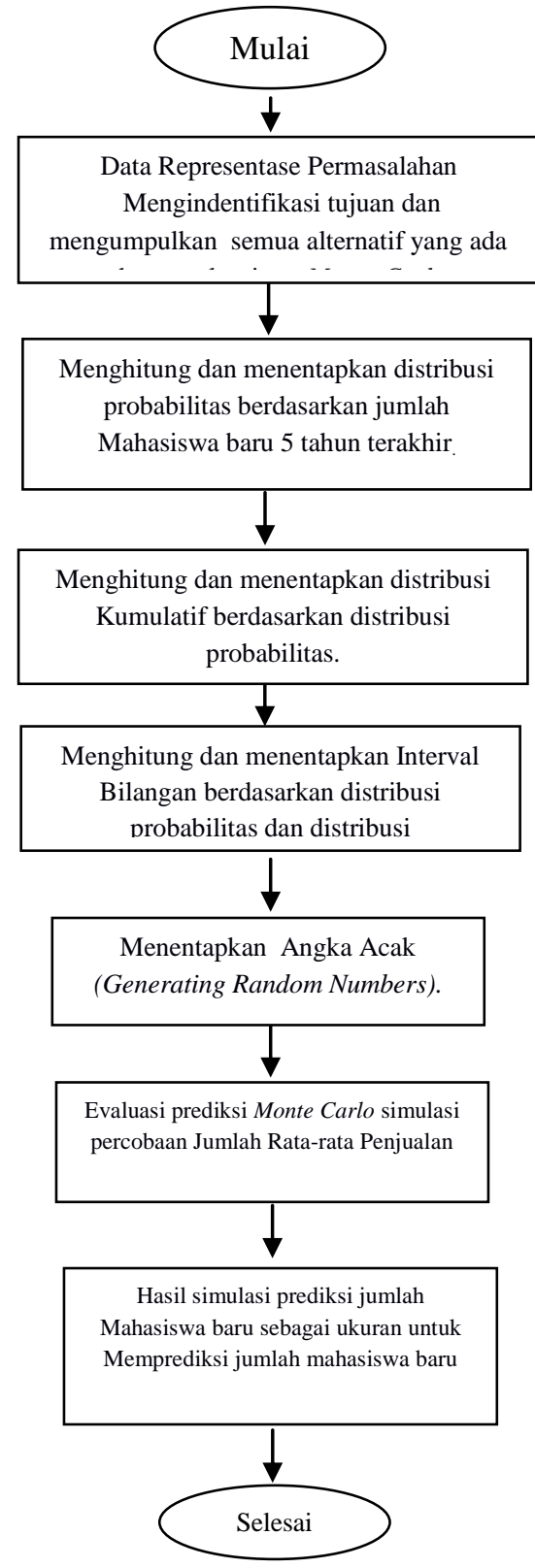

Gambar 2. Arsitektur Sistem Secara Umum

Mekanisme ini bertujuan untuk melihat apakah hasil dari pengujian yang telah dilakukan telah sesuai dengan tujuan yang diharapkan. Mekanisme pengujian untuk membandingkan hasil yang didapatkan pada proses perhitungan dengan menggunakan model simulasi monte carlo untuk memprediksi jumlah mahasiswa baru Universitas Dehasen Bengkulu dengan menggunakan sistem yang telah dirancang. Setelah pengujian dilakukan, hasil pengujian akan dapat dilihat dalam bentuk simulasi apakah dengan metode monte carlo dapat memenuhi harapan dalam mewujudkan tercapainya jumlah penerimaan mahasiswa baru yang sesuai dengan yang diharapkan pihak Universitas Dehasen nantinya sebagai bahan pengambilan keputusan. Mekanisme pengujian ini dapat dilakukan dengan cara sebagai berikut:

1. Melakukan pengujian suatu kasus dengan cara mengumpulkan data-data yang dibutuhkan dalam pengujian perangkat lunak

2. Menentukan hasil yang diharapkan yaitu hasil penelitian data-data terdahulu yang ada di Universitas Dehasen Bengkulu terkait dengan penerimaan mahasiswa baru tiga tahun terakhir dengan melakukan proses perhitungan secara manual.

3. Menjalankan Rancangan Sistem Aplikasi yang telah dirancang untuk mendapatkan nilai nilai acak terhadap kemungkinan kemungkinan yang akan di dapatkan dari penerimaan mahasiswa baru yang akan dilakukan pada tahun ajaran baru

4. Melihat hasil perbandingan pengujian dengan hasil yang diharapkan. Jika terdapat perbedaan hasil, maka akan dilakukan perbaikan sesuai dengan kesalahan yang ditemukan.

A. Teknik-Teknik Penyelesaian Simulasi Monte Carlo

Untuk Tahapan Perhitungan Simulasi Monte Carlo sebagai berikut :

a. Membuat Distribusi Probabilitas dari Variabel. 
Jurnal Pseudocode, Volume VII Nomor 1, Februari 2020, ISSN 2355-5920, e-ISSN 2655-1845 www.ejournal.unib.ac.id/index.php/pseudocode

\begin{tabular}{|c|c|c|c|}
\hline \multirow{2}{*}{\multicolumn{4}{|c|}{$\begin{array}{l}\text { Berikut merupakan perhitungan untuk } \\
\text { distribusi probabilitas penerimaan mahasiswa } \\
\text { baru program studi Teknologi Pertanian } \\
\text { (41201) dalam lima tahun kebelakang dan } \\
\text { sekaligus cara hitungan ini dapat diikuti semua } \\
\text { program studi lainnya. }\end{array}$}} \\
\hline & & & \\
\hline \multicolumn{4}{|c|}{$2013=29 / 95=0,305$} \\
\hline \multicolumn{4}{|c|}{$2014=22 / 95=0,232$} \\
\hline \multicolumn{4}{|c|}{$2015=11 / 95=0,116$} \\
\hline \multicolumn{4}{|c|}{$2016=10 / 95=0,105$} \\
\hline \multicolumn{4}{|c|}{$2017=23 / 95=0,242$} \\
\hline \multicolumn{4}{|c|}{ Bisa dilihat pada tabel 1} \\
\hline Kode & Periode & $\begin{array}{c}\text { Jumlah } \\
\text { Mahasiswa }\end{array}$ & Probabilitas \\
\hline \multirow{5}{*}{41201} & 2013 & 29 & 0.305 \\
\hline & 2014 & 22 & 0.232 \\
\hline & 2015 & 11 & 0.116 \\
\hline & 2016 & 10 & 0.105 \\
\hline & 2017 & 23 & 0.242 \\
\hline \multicolumn{2}{|l|}{ Total } & 95 & \\
\hline
\end{tabular}

b. Menghitung Distribusi Kemungkianan

Kumulatif dari variabel distribusi probabilitas.

Konversi dari distribusi probabilitas biasa menjadi distribusi kumulatif, yaitu Dengan cara menjumlahkan setiap angka kemungkinan dengan jumlah sebelumnya. Berikut merupakan perhitungan perhitungan distribusi untuk kemungkinan kumulatif penerimaan mahasiswa baru program studi Teknologi Pertanian (41201) dalam lima tahun kebelakang dan sekaligus cara hitungan ini dapat diikuti semua program studi lainnya.

$$
\begin{aligned}
& 2013=0,305 \\
& 2014=0,305+0,232=0,537 \\
& 2015=0,537+0,116=0,653 \\
& 2016=0,653+0,105=0,758 \\
& 2017=0,758+0,242=1,000
\end{aligned}
$$

Seperti yang terlihat pada tabel 2.

Tabel 2. Probabilitas Penerimaan Mahasiswa Baru

\begin{tabular}{|c|c|c|c|c|}
\hline Kode & Periode & $\begin{array}{c}\text { Jumlah } \\
\text { Mahasiswa }\end{array}$ & Probabilitas & Kumulatif \\
\hline \multirow{4}{*}{41201} & 2013 & 29 & 0.305 & 0.305 \\
\cline { 2 - 5 } & 2014 & 22 & 0.232 & 0.537 \\
\cline { 2 - 5 } & 2015 & 11 & 0.116 & 0.653 \\
\cline { 2 - 5 } & 2016 & 10 & 0.105 & 0.758 \\
\cline { 2 - 5 } & 2017 & 23 & 0.242 & 1.000 \\
\hline \multicolumn{2}{|c|}{ Total } & 95 & 1 & \\
\hline
\end{tabular}

c. Membuat Interval dari masing-masing variable

Bilangan Acak yang digunakan adalah bilangan acak 3 dijid dikarenakan nilai distribusi probabilitas dan probilitas kumulatif memiliki 3 dijid belakang koma. Adapun interval bilangan acak tersebut perhitungannya akan dicontohkan dengan mengambil sampel program studi Teknologi Pertanian (41201) sekaligus cara perhitungan ini dapat diikuti semua program studi lainnya.

$$
\begin{aligned}
& 2013=000 \mathrm{~s} / \mathrm{d}(0,305 * 1000)-1 \\
& =000-304 \\
& 2014=304 \mathrm{~s} / \mathrm{d}(0,537 * 1000)-1 \\
& =305-536 \\
& 2015=536 \mathrm{~s} / \mathrm{d}(0,653 * 1000)-1 \\
& =537-652 \\
& 2016=652 \mathrm{~s} / \mathrm{d}(0,758 * 1000)-1 \\
& =653-757 \\
& 2017=757 \mathrm{~s} / \mathrm{d}(1,000 * 1000)-1 \\
& =758-999
\end{aligned}
$$

Penentuan nilai interval ini adalah perhitungan terakhir sebelum memasuki penentuan angka acak (Generating Random Number). Dapat dilihat pada tabel 3 . 
Jurnal Pseudocode, Volume VII Nomor 1, Februari 2020, ISSN 2355-5920, e-ISSN 2655-1845 www.ejournal.unib.ac.id/index.php/pseudocode

Tabel 3. Interval bilangan acak dari Probabilitas Kumulatif

\begin{tabular}{|l|l|l|l|l|l|}
\hline Kode & Periode & Probabilitas & Kumulatif & \multicolumn{2}{|c|}{ Interval } \\
\hline \multirow{4}{*}{41201} & 2013 & 0.305 & 0.305 & 000 & 304 \\
\cline { 2 - 6 } & 2014 & 0.232 & 0.537 & 305 & 536 \\
\cline { 2 - 6 } & 2015 & 0.116 & 0.653 & 537 & 652 \\
\cline { 2 - 6 } & 2016 & 0.105 & 0.758 & 653 & 757 \\
\cline { 2 - 6 } & 2017 & 0.242 & 1.000 & 758 & 999 \\
\hline
\end{tabular}

d. Membentuk bilangan acak (Generating Random Numbers)

Langkah Selanjutnya adalah membentuk bilangan acak yaitu dengan rumus dan ketentuan sebagai berikut:

Rumus: $\mathrm{Z} i=(a Z i-1+c) m o$

Percobaan Pertama :

$\mathrm{a}=18, \mathrm{c}=27, \mathrm{~m}=99$, dan $\mathrm{Zo}=22$

Mencari nilai $(\mathrm{a} . \mathrm{Zi}+\mathrm{c})$

$=(\mathrm{a} \cdot \mathrm{Zi}+\mathrm{c})$

$=18 * 22+27$

$=423$

Mencari nilai $\mathrm{Zi}+1=(\mathrm{a} \cdot \mathrm{Zi}+\mathrm{c}) \bmod \mathrm{m}$

$=423 \bmod 99$

$=27$

$=270$

Urutkan rangkaian perhitungan tersebut sampai pada tahun terakhir sehingga akan menghasilkan nilai seperti pada tabel 4.

Tabel 4. Generating Random Number

\begin{tabular}{|c|c|c|c|c|}
\hline $\mathrm{i}$ & $\mathrm{Zi}$ & $\begin{array}{c}(\mathrm{a} . \mathrm{Zi})+ \\
\mathrm{C}\end{array}$ & $\begin{array}{c}(\mathrm{a} . \mathrm{Zi}+\mathrm{C}) \\
\bmod \mathrm{m}\end{array}$ & Angka tiga digit \\
\hline 0 & 22 & 423 & 27 & 270 \\
\hline 1 & 27 & 513 & 18 & 180 \\
\hline 2 & 18 & 351 & 54 & 540 \\
\hline 3 & 54 & 99 & 9 & 90 \\
\hline 4 & 9 & 189 & 90 & 900 \\
\hline \multicolumn{7}{c}{ e. Membuat simulasi dari rangkaian } \\
\hline
\end{tabular}

Untuk tahap terakhir yaitu membuat simulasi dari sebuah eksperimen dengan menggunakan bilangan acak dengan mengambil bilangan acak yang telah ditentukan. Adapun simulasi serangkaian percobaan pertama tersebut terlihat pada tabel 5.

Tabel 5. Probabilitas Penerimaan Mahasiswa Baru

\begin{tabular}{|c|c|c|c|c|c|c|c|}
\hline & \multicolumn{5}{|c|}{ Periode } & Tot & $\begin{array}{c}\text { Pre } \\
\text { dik } \\
\text { Ki }\end{array}$ \\
\hline $\begin{array}{c}\text { Kode } \\
4120\end{array}$ & 1 & 2 & 3 & 4 & 5 & 21 & 24 \\
\hline
\end{tabular}

\section{KESIMPULAN DAN SARAN}

\section{A. Kesimpulan}

Setelah dilakukan simulasi dan prediksi jumlah mahasiswa baru Universitas Dehasen Bengkulu menggunakan metode Monte Carlo maka dapat diambil kesimpulan sebagai berikut :

1. Berdasarkan hasil simulasi prediksi jumlah mahasiswa baru Universitas Dehasen Bengkulu menggunakan metode Monte Carlo yang telah dilakukan maka didapatkan nilai prediksi lima tahun kedepan didapatkanlah nilai rata - rata untuk prediksi per lima tahun, per satu tahun dan nilai rata - rata per program studi.

2. Penerapan metode Monte Carlo merupakan sebuah algoritma dengan menggunakan angka acak, maka disetiap angka acak yang digunakan akan menampilkan hasil yang berbeda satu sama lainnya namun tetap merupakan sebuah hasil prediksi. Implementasi dalam menyamakan hasil perhitungan manual serta dari sistem harus dilakukan agar mengetahui ada atau tidak nya perbedaan hasil.

3. Tingkat keakurasian hasil perhitungan manual dengan aplikasi simulasi untuk prediksi menggunakan metode Monte Carlo sangat pas dan tingkat akurasi 100\% .

B. Saran

Adapun saran untuk pengembangan sistem ini antara lain : 
Jurnal Pseudocode, Volume VII Nomor 1, Februari 2020, ISSN 2355-5920, e-ISSN 2655-1845 www.ejournal.unib.ac.id/index.php/pseudocode

1. Simulasi ini dapat dikembangkan lebih lanjut dengan menambahkan beberapa rangkaian percobaan pada bagian Generating Random Number sehingga pengujian prediksinya bisa diseleksi mana yang lebih mendekati.

2. Simulasi prediksi ini kedepannya mungkin dapat ditambahkan dengan metode - metode lainnya tentang prediksi.

3. Simulasi prediksi ini dapat dikembangkan secara online sehingga bisa melihat hasil dari sistem dimanapan user berada.

\section{REFERENSI}

[1] Mahessya R.A., Mardianti L. dan Sovia R, 2017 : Pemodelan dan simulasi sistem antrian pelayanan pelanggan menggunakan metode Monte Carlo pada PT. POS INDONESIA (persero) Padang: Vol. 6 E-ISSN : 2579 - 3918 P-ISSN : 2302 - 710X.

[2] L Liu J., Qi Y., Meng Z.Y dan Fu L., 2016 : Selflearning Monte Carlo method. DOI: 10.1103/PhysRevB.95.041101

[3] Giles M.B., 2015.: Multilevel Monte Carlo methods. DOI:10.1017/S096249291500001X

[4] Agusta A., Arman Y. dan Ihwan A., 2013 : Pemodelan Curah Hujan Bulanan Di Kabupaten Sintang
Menggunakan Metode Monte Carlo dengan Algoritma Metropolis. POSITRON, Vol. III, No. 2 (2013), Hal. 32 -34. ISSN : 2301-4970.

[5] Isamael I.,2012 : Faktor-faktor Risiko yang Berpengaruh Terhadap Kinerja Kualitas Proyek Konstruksi Gedung di Kota Padang Sumatera Barat Dengan menggunakan Model dan Simulasi Monte Carlo. Jurnal Momentum Vol.13 No.2. Agustus 2012. ISSN : 1693-752X. ISSN: 2337-9197.

[6] Arwindy F.,Buulolo F. dan Rosmaini E., 2014 : Analisis dan simulasi sistem antrian pada Bank ABC. Saintia Matematika Vol. 2, No. 2 (2014), pp. 147-162. ISSN: 2337-9197

[7] Margi K. dan Pendawa S., 2015 : Analisa dan penerapan metode Single Exponential Smoothing untuk prediksi penjualan pada periode tertentu. Prosiding SNATIF Ke 2. ISBN: 978-602-1180-21-1

[8] Sunarni T. dan Triana 2014 : Identifikasi risiko dan pengalokasian biaya penanganan risiko dengan simulasi Monte Carlo pada boiler dan peralatan bantu PLTU Sumbagsel. SNATI 2012. ISSN :1907- 5022.

[9] Winda., 2008 : Pendekatan simulasi Monte Carlo untuk pemilihan alternatif dengan Decision Tree pada nilai Outcome yang probabilistik. Teknoin, Volume 13, Nomor 2, Desember 2008, 11-17. ISSN: 0853-8697.

[10] Yogi Y., 2004 : Penentuan prosentase calon mahasiswa baru yang akan mendaftar ulang dengan bantuan simulasi Monte Carlo. KOMMIT 2004. ISSN: 1411-6286. 